\title{
Studi Pola Sebaran Suhu Permukaan Laut Menggunakan Citra Landsat 8 TIRS di Perairan PLTU Banten 3 Lontar, Tangerang
}

\author{
Gita Praspa Ramdhani*, Kunarso, Azis Rifai, Alfi Satriadi dan Dwi Haryo Ismunarti \\ Departemen Oseanografi, Jurusan Ilmu Kelautan Fakultas Perikanan dan Ilmu Kelautan \\ Jl. Prof. H. Sudarto, SH Tembalang, Telp/fax (024) 7474698 Semarang 50275 \\ Email:*gitapraspa@gmail.com
}

\begin{abstract}
Abstrak
PLTU Banten 3 Lontar merupakan salah satu upaya untuk memenuhi kebutuhan utama tenaga listrik di Jakarta dan sekitarnya. Adanya aktivitas PLTU di wilayah pesisir berpengaruh terhadap dinamika parameter hidrooseanografi. Limbah panas yang dihasilkan PLTU memberikan dampak pada lingkungan pesisir salah satunya adalah meningkatkan suhu permukaan air laut. Penelitian ini bertujuan untuk mengetahui pola sebaran spasial suhu permukaan laut secara horizontal serta luas wilayah terdampak limbah air panas di Perairan PLTU Banten 3 Lontar, Tangerang. Penelitian dilakukan dengan menggunakan data yang meliputi Citra Landsat 8 TIRS, suhu permukaan laut lapangan dan data pendukung yakni data angin dari NOAA, data batimetri publikasi BATNAS dan data pasang surut serta peta RBI publikasi BIG. Metode penelitian yang digunakan adalah metode deskriptif dengan metode pengolahan data citra dilakukan menggunakan Google Earth Engine (GEE), sedangkan untuk metode pengambilan sampel menggunakan purposive sampling. Hasil penelitian menunjukkan bahwa wilayah terdampak limbah panas memiliki rentang nilai suhu permukaan laut yaitu $29.01{ }^{\circ} \mathrm{C}-33.00{ }^{\circ} \mathrm{C}$. Penyebaran limbah air panas pada tahun 2019 memiliki total rata- rata luasan mencapai 367.58 ha dan mencapai jarak $1.76 \mathrm{~km}$ dari outfall sedangkan pada tahun 2020 memiliki total rata- rata luasan penyebaran 81.9 ha dan mencapai jarak 1.38 $\mathrm{km}$ dari outfall PLTU Banten 3, Lontar. Pola sebaran suhu permukaan laut dipengaruhi oleh arus pasang surut yang bergerak dengan kecepatan 0.014 - 0.519 m/det dengan dominasi arah sebaran ke Timur Laut.
\end{abstract}

Kata kunci: Landsat 8 TIRS, Suhu Permukaan Laut, GEE, Limbah Air Panas.

\section{Abstract}

PLTU Banten 3 Lontar is one of the power plant to supply the main needs of electricity in Jakarta dan its surroundings. The presence of industrial activities in coastal areas could affects the dynamics of hydrooceanographic parameters. Heat water disposal from PLTU Banten power plant has increased sea surface temperatures dan could caused a negative impact on the coastal environment. This study aims to determine the spatial pattern of sea surface temperature dan heat-affected areas by PLTU Banten 3 Lontar power plant. This study used data includes Landsat 8 Thermal Infrared Sensor (TIRS) data, in-situ temperature measurements data, bathymetry data and map of BATNAS, tidal data, and maps of the RBI from BIG. The research method used descriptive method dan image data processing method with Google Earth Engine (GEE), while the sampling method used purposive sampling method. The results indicate that temperature of heat-affected areas was 29.01 ${ }^{\circ} \mathrm{C}-33.00{ }^{\circ} \mathrm{C}$. Heat water dispersion in 2019 has an average total area of 367.58 ha and could reach distance $1.76 \mathrm{~km}$ from the outfall, while in 2020 it has a total average distribution of $81.9 \mathrm{ha}$ and $1.38 \mathrm{~km}$ away from the outfall of PLTU Banten 3, Lontar. The result show that the spatial distribution is was dominated by tidal currents with a current velocity of $0.014-0.519 \mathrm{~m} / \mathrm{s}$ dan flow to Northeastward.

Keywords : Landsat 8 TIRS Image, Sea Surface Temperature, GEE, Hot water.

\section{PENDAHULUAN}

Indonesia merupakan sebuah negara kepulauan dengan populasi lebih dari 220 juta orang yang merupakan sumber daya pembangunan yang sangat potensial. Peningkatan energi listrik dan perbaikan kendala distribusi tenaga listrik sangat penting dalam mendukung kehidupan sumber daya manusia. Pembangunan Pembangkit Listrik Tenaga Uap (PLTU) di Indonesia merupakan salah satu upaya untuk memenuhi kebutuhan utama tenaga listrik masyarakat Indonesia. Berdasarkan Perpres No. 71 tahun 2006 PLTU Banten 3 Lontar merupakan salah satu proyek listrik percepatan 10.000 MW di Pulau Jawa yang beroperasi di pesisir pantai berbahan bakar batubara.

Pengoperasian PLTU dibutuhkan air laut sebagai pendingan kondensor yang kemudian dialirkan ke laut melalui kanal-kanal discharge sehingga terjadi kegiatan pembuangan air pendingin (cooling water). Hal tersebut menyebabkan adanya input panas karena air pendingin memiliki suhu 
yang lebih hangat dibandingkan dengan suhu air sebelum dipakai untuk pendingin (Fudlailah dan Zikra, 2013). Air pendingin atau yang dikenal sebagai air bahang atau air buangan yang dibuang ke laut tanpa melalui proses pendinginan kembali dapat menyebabkan pengaruh atau dampak terhadap perairan, baik secara langsung maupun tidak langsung terhadap organisme yang hidup di dalamnya (Surinati dan Marfatah, 2019).

Kegiatan pembuangan air pendingin berdampak pada peningkatan suhu air laut. Suhu air laut salah satu parameter oseanografi yang memegang peranan penting di dalam ekosistem perairan (Akhbar et al., 2018). Menurut Nontji (2007) suhu permukaan laut di Indonesia berkisar antara $28^{\circ} \mathrm{C}$ $31{ }^{\circ} \mathrm{C}$ namun untuk di daerah sekitar pembuangan limbah industri atau pembangkit listrik dapat terjadi kenaikan suhu permukaan mencapai $37^{\circ} \mathrm{C}$. Cairns (1972) dalam (Ismayati et al., 2013) mengemukakan bahwa, kenaikan suhu perairan mempengaruhi berbagai sifat kimia dan fisika yang berhubungan dengan kualitas air (oksigen terlarut, $\mathrm{CO} 2, \mathrm{pH}$, densitas dan viskositas) serta kehidupan organisme perairan. Perubahan suhu perairan berpengaruh terhadap kelarutan oksigen dalam air, semakin tinggi suhu maka kelarutan oksigen dalam air semakin rendah sehingga kandungan oksigen terlarut akan kecil (Rosen et al., 2015). Dengan demikian suhu permukaan laut dapat digunakan sebagai indikasi penentuan kualitas suatu perairan (Tampubolon et al., 2017).

Berdasarkan hal tersebut perlu adanya studi mengenai dampak pembuangan limbah panas PLTU tersebut terhadap suhu permukaan laut sehingga dapat dijadikan informasi dalam pemantauan kondisi ekosistem di wilayah perairan tersebut. Studi ini dilakukan dengan analisa spasial sebaran suhu permukaan laut akibat limbah panas PLTU Banten 3 Lontar dengan menggunakan citra satelit Landsat 8 dan diharapkan dapat menggambarkan luas wilayah yang terkena dampak limbah panas tersebut serta dapat mengetahui perubahan suhu permukaan laut.

\section{MATERI DAN METODE PENELITIAN Materi Penelitian}

Materi pada penelitian ini meliputi data primer dan data sekunder. Data primer berupa data suhu hasil pengukuran lapangan pada 31 Oktober 2020. Data suhu tersebut akan digunakan untuk verifikasi data hasil analisa citra satelit. Sedangkan data sekunder berupa data Citra Termal Satelit Landsat 8 tahun 2019- 2020 resolusi 30 m yang diolah dan dianalisa untuk menghasilkan sebaran suhu permukaan laut, selanjutnya data arus pasang surut pemodelan MIKE21. Selain itu terdapat data pengamatan pasang surut dari Tides BIG, dan data kedalaman perairan.

\section{Metode Penelitian}

Metode penelitian yang digunakan adalah metode deskriptif yang merupakan metode penelitian untuk membuat gambaran mengenai situasi atau kondisi secara lokal yang diteliti atau dikaji pada waktu terbatas dan tempat tertentu (Ismayati et al., 2013). Metode deskriptif pada penelitian ini untuk mendapatkan gambaran tentang kejadian sebaran suhu permukaan laut yang dipengaruhi oleh limbah air panas PLTU Banten 3 Lontar. Data pada penelitian ini merupakan data yang telah dikumpulkan, diproses, dan dianalisis berdasarkan masalah serta tujuan penelitian yang hendak dicapai sesuai dengan teori yang telah dipelajari.

\section{Metode Pengukuran Suhu Permukaan Laut Lapangan}

Metode yang digunakan dalam pengambilan data lapangan yakni menggunakan metode purposive sampling sebanyak 13 titik yang dianggap telah mewakili daerah penelitian. Penentuan titik sampling didasarkan pada letak Intake dan Outfall serta arah arus perairan sekitarnya. Pertimbangan selanjunya yaitu pada pendugaan air limbah dari PLTU tersebut menyebar secara merata sehingga diharapkan dapat ditentukan arah sebaran sebenarnya dari hasil pengukuran pada stasiun sampling tersebut. Pengambilan data suhu permukaan laut dilakukan di perairan PLTU Banten 3 Lontar pada pukul 10.00-11.00 WIB dengan kondisi perairan surut menuju pasang.

\section{Metode Pengolahan Data}

\section{Citra Satelit Landsat- 8}

Data Citra Satelit Landsat 8 tahun 2019-2020 diperoleh dari USGS (http://glovis.usgs.gov/) dengan lokasi path 122 dan row 64 pada wilayah PLTU Banten 3 Lontar kemudian diolah dengan platform Google Earth Engine. Data citra satelit Landsat 8 yang digunakan dengan mengoptimalkan 
saluran TIR 10 dengan panjang gelombang 10.60 - $11.19 \mathrm{~mm}$. Pengolahan data yang dilakukan pada 2019-2020 menghasilkan 14 data citra dengan nilai tutupan awan rendah yang kemudian akan dilakukan visualisasi dengan ArcGIS. Hasil yang ditampilkan dalam penelitian ini didasarkan pada luas sebaran suhu permukaan laut terbesar, nilai suhu tertinggi dan data lapangan yang digunakan sebagai verifikasi data (Gambar 2).

Pengolahan data yang dilakukan menggunakan platform Google Earth Engine melalui tahapan seperti pada gambar 1 dan dijelaskan lebih rinci pada bagian berikut. Dalam penelitian ini naskah pemrograman yang digunakan dibagi menjadi dua tahapan yaitu :

1. Filter Bebas Awan

https://code.earthengine.google.com/dc7dd87ba66d78bd2dfc74d02b1ba644?noload=true

Untuk memastikan Citra Landsat 8 TIRS memiliki tutupan awan yang rendah sehingga dapat digunakan dalam analisa suhu.

2. Export Data Citra

https://code.earthengine.google.com/4add4caa308fcbbb904496bf166eb53d?noload=true

Untuk menghitung nilai Digital Numbers (DNs) dari band 10 Citra Landsat 8 TIRS. Penghitungan brightness temperatures $(\mathrm{Tb})$ dari Digital Numbers menggunakan metode Normalized Difference Vegetation Index (NDVI). Penggunaan NDVI umumnya digunakan untuk mengetahui indeks kerapatan suatu vegetasi (Mukhlisin and Soemarno, 2020). Berdasarkan penelitian (Cherif et al., 2019), Permukaan darat dan laut dibedakan karena reflektansi air hampir sama dengan nol, sedangkan reflektansi tutupan vegetasi lebih besar dibandingan dengan reflektansi air.

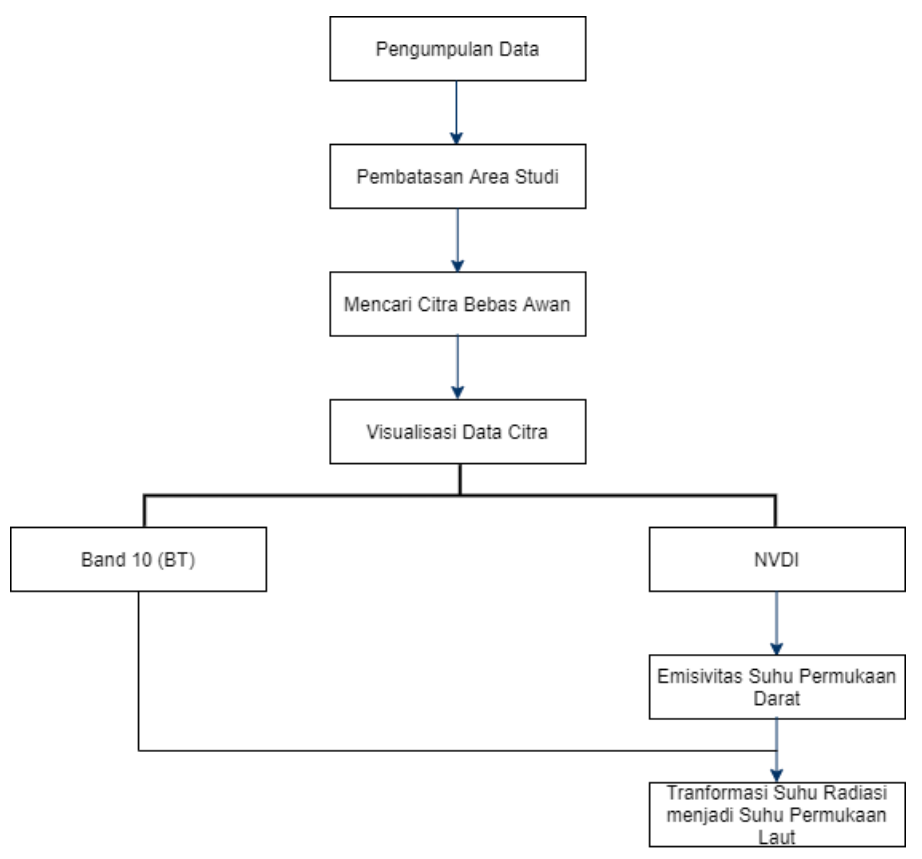

Gambar 1. Diagram Alir Pengolahan Data menggunakan Google Earth Engine

3. Transformasi Suhu Radiasi Menjadi Suhu Permukaan Laut

Nilai brightness temperatures yang diperoleh diubah menjadi nilai suhu permukaan laut menggunakan persamaan dibawah ini. Metode ini digunakan pada saat keterbatasan sampel data insitu pada saat akuisisi data satelit Landsat, atau tidak ada data satelit resolusi spasial yang lebih tinggi dari Landsat dan sudah terkalibrasi. Berdasarkan nilai suhu radiasi hasil kalkulasi, nilai suhu kinetik objek dapat dihitung dengan persamaan berikut: 


DST $=\mathrm{AT}^{3}-\mathrm{BT}^{2}+\mathrm{CT}-$
Dimana
SST $\quad$ Sea Surface Temperature / Suhu Permukaan Laut
$\mathrm{A} \quad: 0,0684$
$\mathrm{~B} \quad: 5,3082$
$\mathrm{C} \quad: 137,59$
$\mathrm{~T} \quad:$ Suhu Radiasi (Celcius)

(Trisakti et al., 2004)

\section{Pemodelan MIKE 21Arus Pasang Surut}

Pemodelan arus permukaan pasang surut menggunakan data kedalaman yang dirilis oleh BIG yang diakses melalui (https://tanahair.indonesia.go.id/demnas/\#/batnas). Sebelum dilakukan pemodelan dengan software MIKE21 dibuat batasan daerah penelitian dengan memasukkan data garis pantai dan data kedalaman melalui software ArcGIS. Data arus pasang surut permukaan yang dihasilkan berupa koordinat dan data kecepatan serta arah arus dengan waktu yang telah ditentukan. Data tersebut selanjutnya ditampilkan dalam bentuk peta 2D.

\section{Pasang Surut}

Masukan data yang digunakan berupa pengukuran pasang surut dari Tides BIG selama satu bulan. Data pasang surut yang diperoleh berupa data elevasi muka air laut dengan interval selama 60 menit. Peninjauan komponen pasang surut di lokasi penelitian didasarkan oleh pengolahan data menggunakan t_tide toolbox dalam perangkat lunak Matlab. Komponen yang diperoleh dapat menjelaskan tipe pasang surut pada lokasi penelitian melalui perhitungan bilangan Formzahl.

\section{Tahap Verifikasi}

Verifikasi data suhu Citra Satelit Landsat-8 dengan data suhu hasil pengukuran lapangan dilakukan dengan membandingkan nilai suhu pada stasiun-stasiun pengamatan. Metode yang digunakan dalam tahap verifikasi dan validasi ini adalah MRE (Mean Relative Error) atau koreksi kesalahan relatif. Menurut (Neill dan Hashemi, 2018) menyatakan bahwa Root Mean Square Error (RMSE) merupakan besarnya tingkat kesalahan hasil prediksi, dimana semakin kecil (mendekati 0) nilai RMSE maka hasil prediksi akan semakin akurat. Nilai kesalahan dapat dihitung menggunakan rumus :

1. Kesalahan Relatif [Relative Error (RE)]

$$
\mathrm{RE}=\left|\frac{P-P^{*}}{P}\right|
$$

2. Kesalahan Relatif Rata-Rata [ Mean Relative Error (MRE)]

$$
\operatorname{MRE}=\frac{1}{n} \sum_{i=1}^{n}\left|\frac{P-P^{*}}{P}\right| \times 100 \%
$$

\section{HASIL}

\section{Suhu Permukaan Laut}

Berdasarkan pengolahan Citra Landsat 8 TIRS maka diperoleh hasil suhu permukaan laut dari masing-masing perekaman yaitu pada tahun 2019-2020 (Gambar 2). Dampak pembuangan limbah panas dari pembangkit listrik terhadap suhu permukaan laut memiliki pola persebaran yang didominasi menuju ke arah Timur Laut dengan intensitas kenaikan suhu permukaan laut menurun dari outfall dan menjauhi garis pantai. Daerah yang diperkirakan terdampak dari limbah air panas memiliki rentang nilai suhu permukaan laut yaitu $29.01{ }^{\circ} \mathrm{C}-33.00{ }^{\circ} \mathrm{C}$. Gambar 2e menunjukkan bawah suhu tertinggi dengan rentang nilai $32.01{ }^{\circ} \mathrm{C}-33.00{ }^{\circ} \mathrm{C}$ tersebar seluas 13.98 ha dan berada dalam jarak 0.94 dari outfall sedangkan daerah dengan rentang nilai $31.01{ }^{\circ} \mathrm{C}-32.00{ }^{\circ} \mathrm{C}$ memiliki luas 4.31 ha dan berada sejauh $0.38 \mathrm{~km}$ dari outfall. Hasil pengolahan data (Gambar 2.b,d,e) menunjukkan daerah dengan nilai suhu 30.01-31.00 memiliki luasan rata- rata sebesar 62.54 ha dan berada dalam jarak $1.28 \mathrm{~km}$ dari outfall. Daerah dengan rentang suhu 29.01-30.00 mencakup area yang relatif terbesar dengan rata- rata luasan mencapai 328.877 ha dan sebagian besar berada dalam jarak $1.85 \mathrm{~km}$ dari outfall (Gambar 2.a, c, f, g, $\mathrm{i}, \mathrm{j}, \mathrm{k}, \mathrm{l}, \mathrm{m})$. Suhu permukaan laut hasil pengukuran di lapangan memiliki rentang nilai yaitu $31.01{ }^{\circ} \mathrm{C}-$ $37.00^{\circ} \mathrm{C}$ (Gambar 2o). Nilai yang ditunjukkan merupakan hasil interpolasi berdasarkan nilai tertinggi 
dan terendah dari data yang telah didapatkan. Area yang memiliki nilai suhu tertinggi sebesar $36.01{ }^{\circ} \mathrm{C}$ - $37.00{ }^{\circ} \mathrm{C}$ yang dimana terkonsentrasi dalam jarak $0.92 \mathrm{~km}$ dari titik outfall.

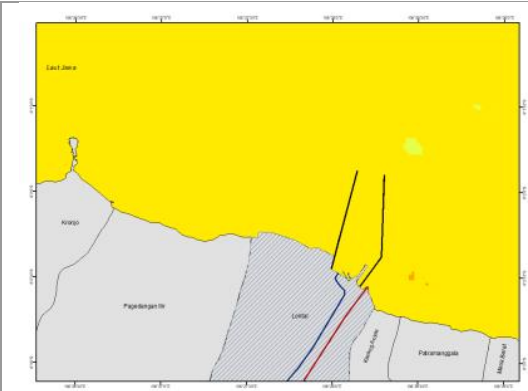

a

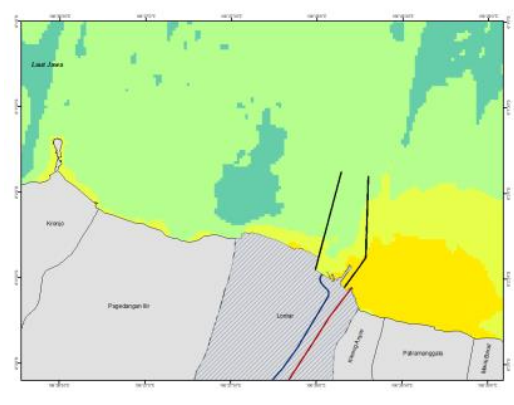

c

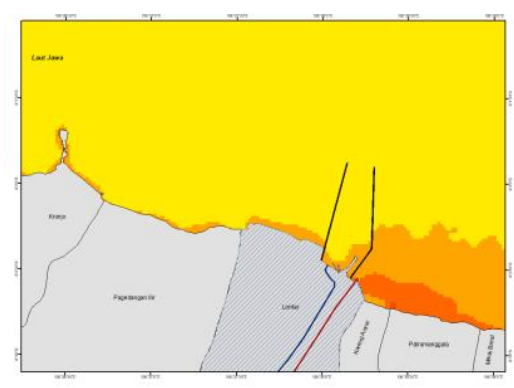

$\mathrm{e}$

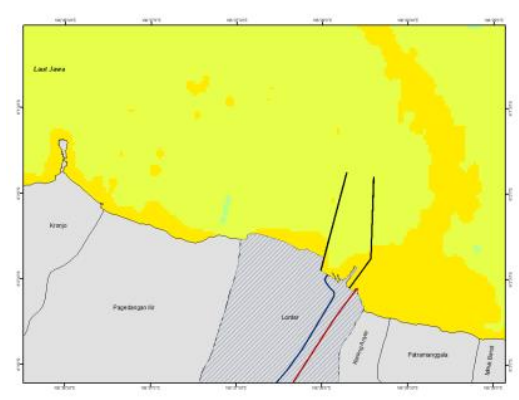

g

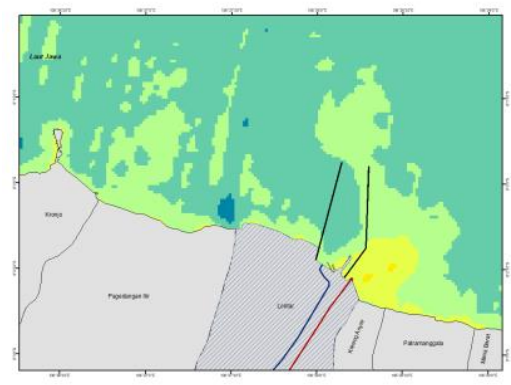

j

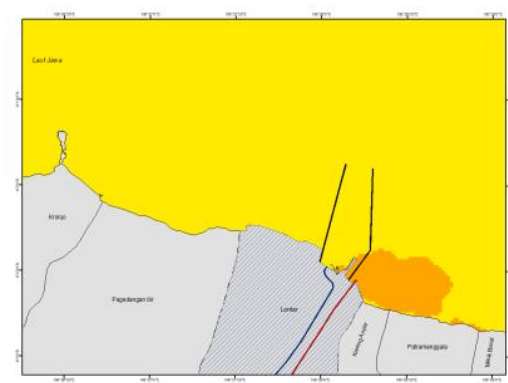

b

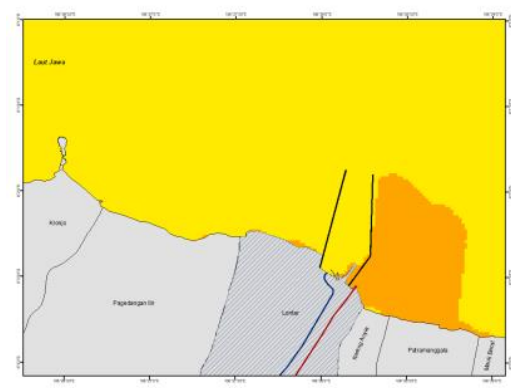

d

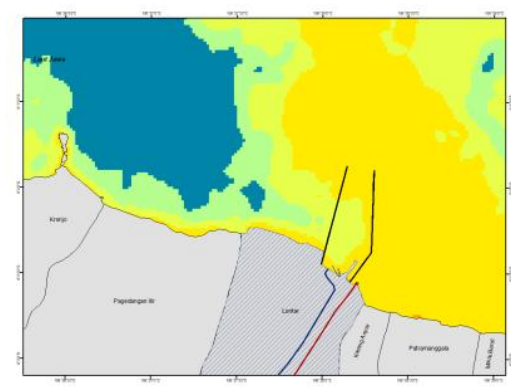

$\mathrm{f}$

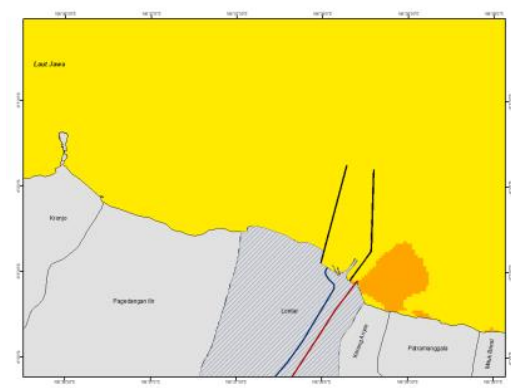

$\mathrm{h}$

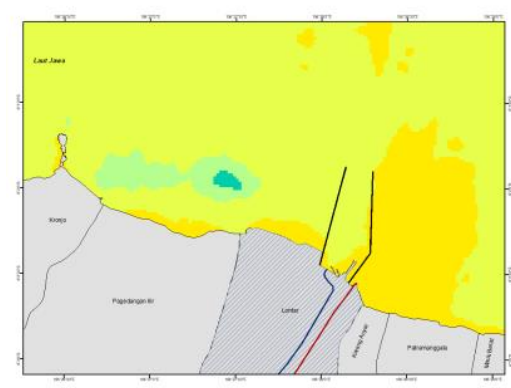

$\mathrm{k}$

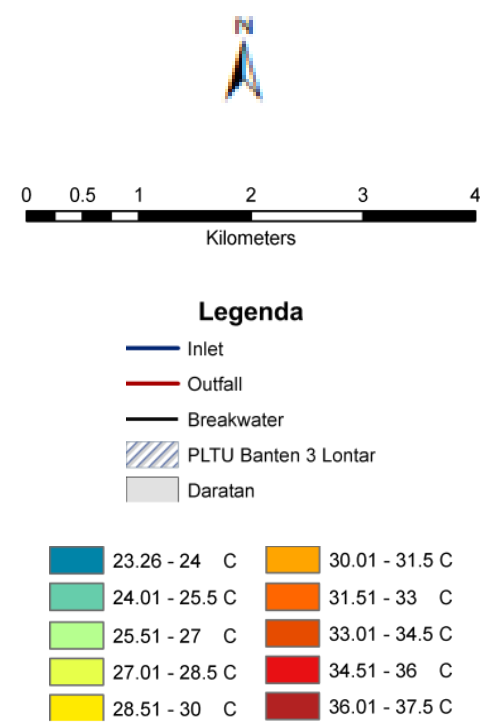

\section{Sumber Peta:}

1. Peta Rupa Bumi Indonesia $1: 25.000$ 2. Peta Adendum Andal, Rencana Penaembanaan Unit 4 PLTU Banten 3
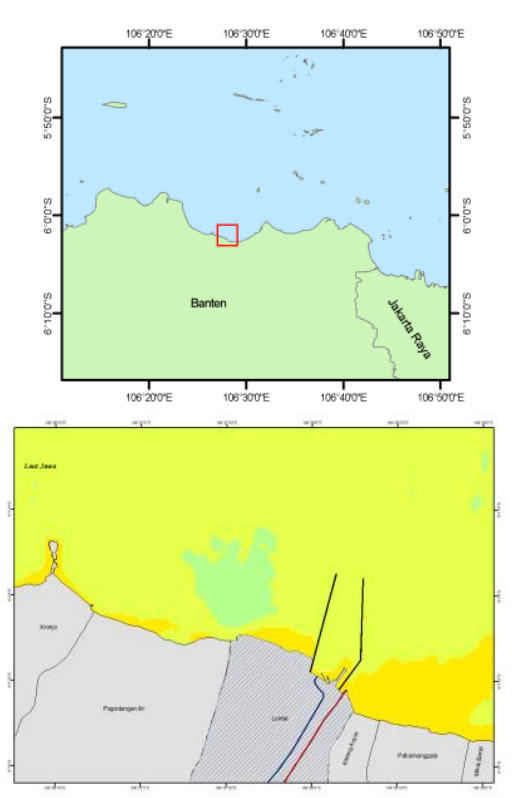

i

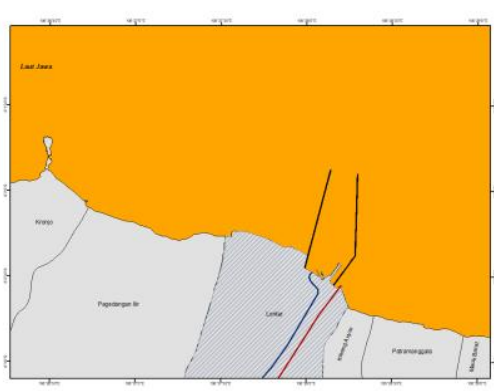

1

Diterima/Received : 01-10-2021

Disetujui/Accepted : 29-11-2021 


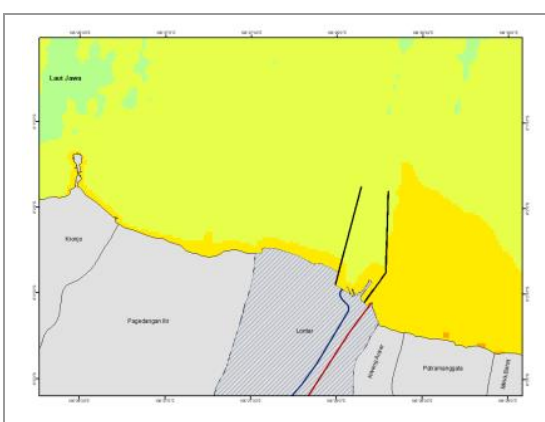

$\mathrm{m}$

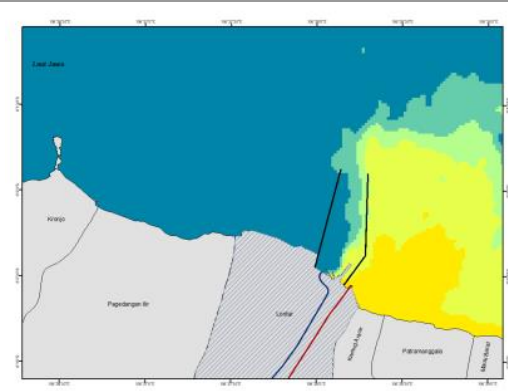

$\mathrm{n}$

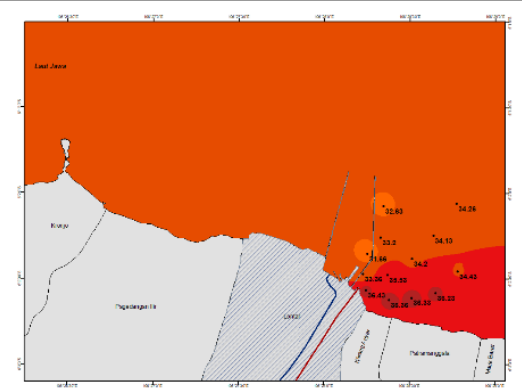

o

Gambar 2. Peta Sebaran SPL Pengolahan Citra Landsat 8 TIRS Pukul 03.00 WIB; a) 22 Mei 2019, b) 30 Juni 2019, c) 9 Juli 2019, d) 10 Agustus 2019, e) 18 September 2019, f) 04 Oktober 2019, g) 17 Januari 2020, h) 22 April 2020, i) 24 Mei 2020, j) 16 Juni 2020, k) 11 Juli 2020, l) 28 Agustus 2020, m) 13 September 2020, n) 15 Oktober 2020, o) Peta Sebaran SPL Lapangan Tanggal 31 Oktober 2020 Pukul 10.00-11.00 WIB.

Tabel 1. Perbandingan Distribusi Suhu Permukaan Laut Tahun 2019-2020

\begin{tabular}{|c|c|c|c|c|c|}
\hline Gambar & Tanggal & Luas (ha) & Jarak (km) & Arah Dominan & Nilai SPL $\left({ }^{\circ} \mathrm{C}\right)$ \\
\hline $2 \mathrm{a}$ & 22 Mei 2019 & 2162.5 & 3.13 & Timur Laut & $29.01-30.00$ \\
\hline $2 b$ & 30 Juni 2019 & 50.4 & 1.06 & Timur & $30.01-31.00$ \\
\hline $2 c$ & 9 Juli 2019 & 130.9 & 1.53 & Tenggara & 29.01-30.00 \\
\hline $2 d$ & 10 Agustus 2019 & 50.4 & 1.51 & Timur Laut & $30.01-31.00$ \\
\hline \multirow{3}{*}{$2 \mathrm{e}$} & \multirow{3}{*}{18 September 2019} & 113.39 & 1.62 & \multirow{3}{*}{ Tenggara } & $30.01-31.00$ \\
\hline & & 31.66 & 1.68 & & $31.01-32.00$ \\
\hline & & 13.98 & 0.94 & & $32.01-33.00$ \\
\hline $2 \mathrm{f}$ & 04 Oktober 2019 & 382.32 & 2.56 & Barat Laut & $29.01-30.00$ \\
\hline $2 g$ & 12 Januari 2020 & 83.60 & 1.62 & Tenggara & $29.01-30.00$ \\
\hline $2 \mathrm{~h}$ & 22 April 2020 & 36 & 0.88 & Timur Laut & $30.01-31.00$ \\
\hline $2 \mathrm{i}$ & 24 Mei 2020 & 60.2 & 1.66 & Tenggara & $29.01-30.00$ \\
\hline $2 \mathrm{j}$ & 16 Juni 2020 & 20.2 & 0.62 & Timur Laut & $28.01-29.00$ \\
\hline $2 \mathrm{k}$ & 11 Juli 2020 & 88.3 & 1.11 & Timur Laut & $29.01-30.00$ \\
\hline 21 & 28 Agustus 2020 & 121.8 & 1.62 & Tenggara & $29.01-30.00$ \\
\hline $2 \mathrm{~m}$ & 13 September 2020 & 184.30 & 1.62 & Timur Laut & $29.01-30.00$ \\
\hline $2 n$ & 15 Oktober 2020 & 60.80 & 1.62 & Timur Laut & $29.01-30.00$ \\
\hline 20 & 31 Oktober 2020 & 36.66 & 0.92 & Timur Laut & $36.01-32.00$ \\
\hline
\end{tabular}

Berdasarkan data pada Tabel 1 menunjukkan perbandingan distribusi suhu permukaan laut tahun 2019-2020. Data tersebut menunjukkan bahwa hasil pengolahan data citra perekaman 04 Oktober 2019 memiliki area terdampak terluas yaitu sebesar 382.37 ha dan berjarak sejauh $2.56 \mathrm{~km}$ dari outfall PLTU. Dampak limbah panas terhadap suhu permukaan laut di perairan meningkatkan nilai suhu mencapai $33.03{ }^{\circ} \mathrm{C}$ yang ditunjukkan pada citra perekaman 18 September 2019 (Gambr 2d). Total luas rata- rata area yang terdampak limbah panas di perairan sebesar 213.67 ha dan terkonsetrasi dalam jarak sekitar $1.53 \mathrm{~km}$ dati outfall PLTU Banten 3 Lontar. $1.06 \mathrm{~km}$.

Berdasarkan pengolahan data pasang surut (Gambar 3), dapat diketahui bilangan Formzahl sebesar 2.06. Hal ini menunjukkan bahwa tipe pasang surut perairan PLTU Banten 3 Lontar merupakan tipe pasang surut campuran condong ke harian tunggal. Nilai MSL sebesar $83 \mathrm{~cm}$, HHWL sebesar 42.4 cm di atas MSL, dan LLWL sebesar $-40.8 \mathrm{~cm}$ di bawah MSL. 
Tabel 2. Nilai RMSE Suhu Permukaan Laut 31 Oktober 2020

\begin{tabular}{cccccc}
\hline Titik Sample & $\mathbf{X}$ & $\mathbf{Y}$ & SPL Lapangan & Landsat 8 & $\mathbf{R E}$ \\
\hline 1 & 662220.9388 & -668152.0454 & 36.43 & 29.43 & 0.192 \\
\hline 2 & 662240.892 & -662923.5922 & 33.32 & 28.12 & 0.156 \\
\hline 3 & 663019.6681 & -668254.8296 & 36.32 & 29.43 & 0.191 \\
\hline 4 & 663264.9662 & -668231.6005 & 36.33 & 29.43 & 0.190 \\
\hline 5 & 663005.2538 & -662983.9155 & 35.53 & 29.04 & 0.183 \\
\hline 6 & 662289.5216 & -662256.8859 & 31.62 & 22.65 & 0.122 \\
\hline 2 & 663524.8331 & -668183.0992 & 36.23 & 29.43 & 0.188 \\
\hline 8 & 663269.5228 & -662812.4153 & 34.20 & 28.22 & 0.160 \\
\hline 9 & 662929.9123 & -662582.0549 & 33.20 & 28.32 & 0.142 \\
\hline 10 & 663260.3806 & -662950.6432 & 34.43 & 28.94 & 0.160 \\
\hline 11 & 663499.8323 & -662561.0355 & 34.13 & 28.6 & 0.162 \\
\hline 12 & 662961.5435 & -662243.292 & 32.63 & 22.83 & 0.142 \\
\hline 13 & 663249.5212 & -662216.1615 & 34.22 & 28.12 & 0.128 \\
\hline
\end{tabular}

\section{Pasang Surut}

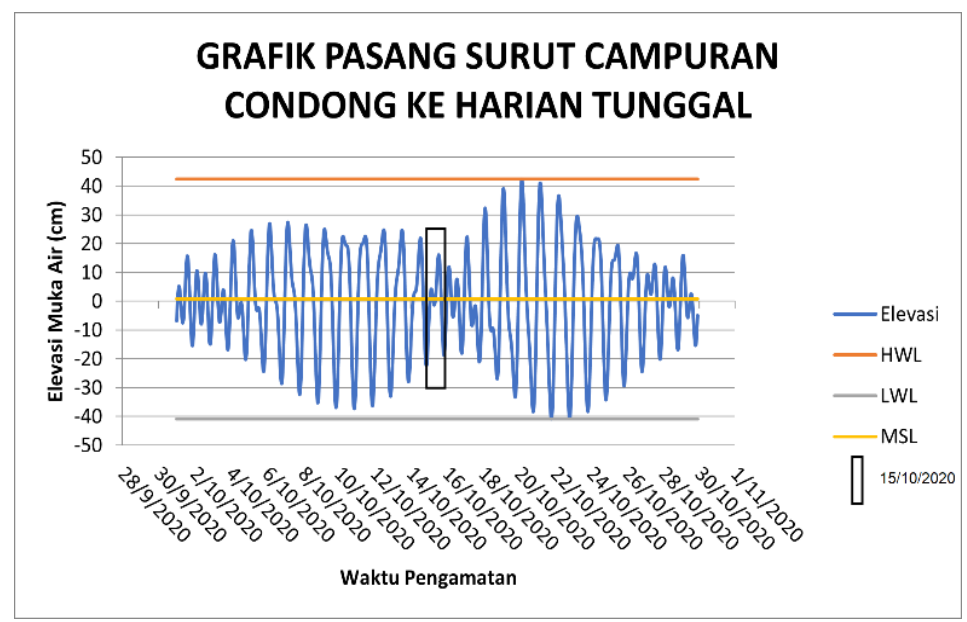

Gambar 3. Grafik Pasang Surut Bulan Oktober 2020

\section{Arus Pasang Surut}

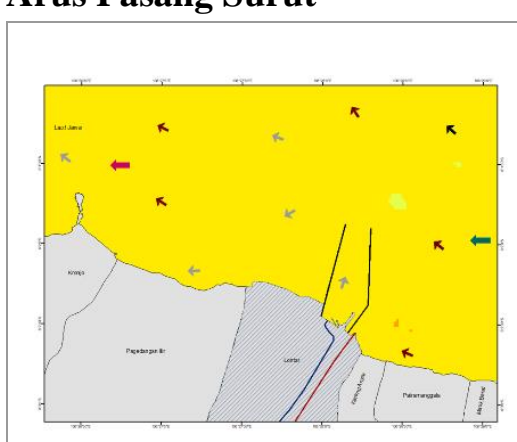

a

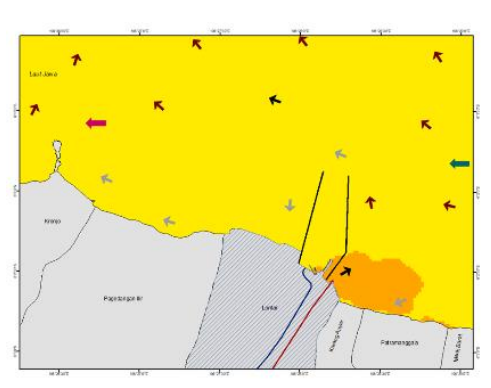

$\mathrm{b}$

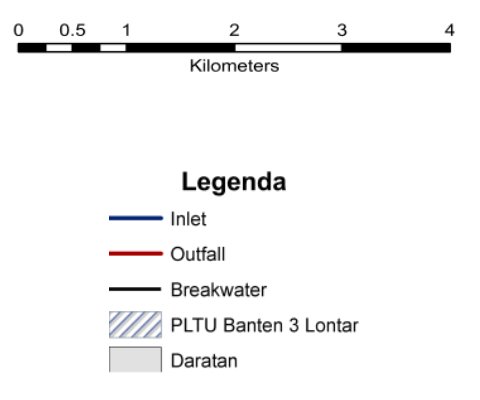




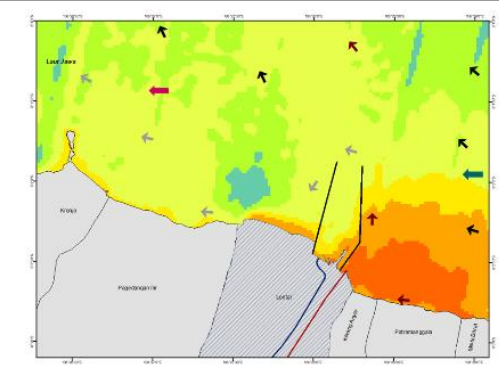

$\mathrm{c}$

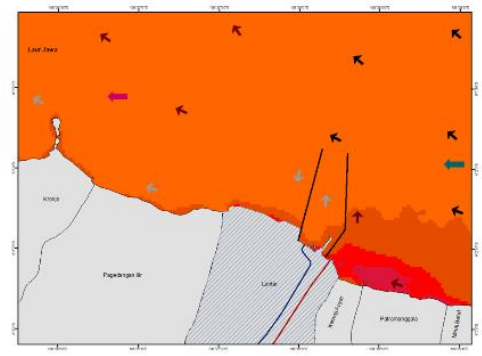

$\mathrm{e}$

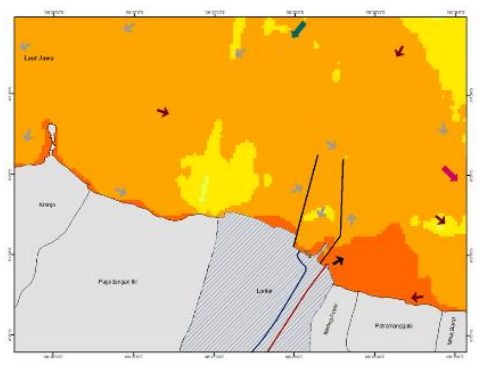

$\mathrm{g}$

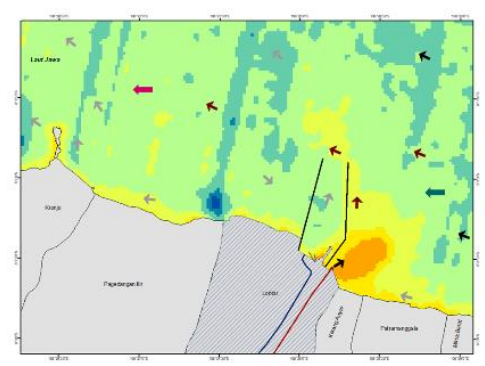

j

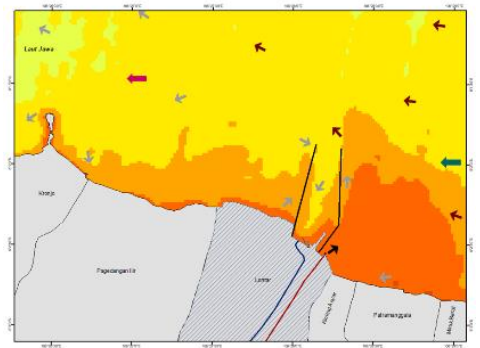

m

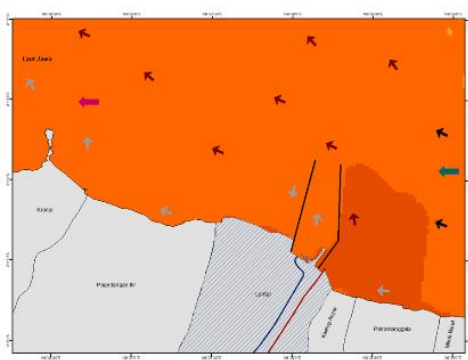

$\mathrm{d}$

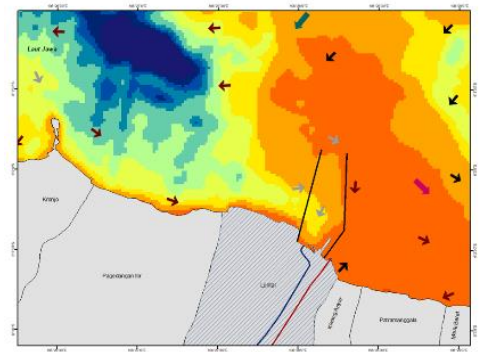

f

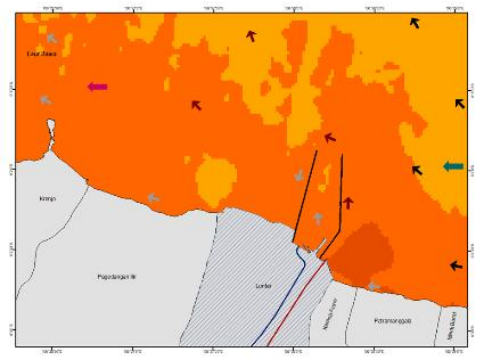

$\mathrm{h}$

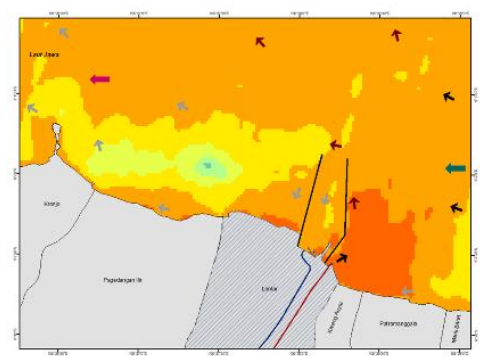

$\mathrm{k}$

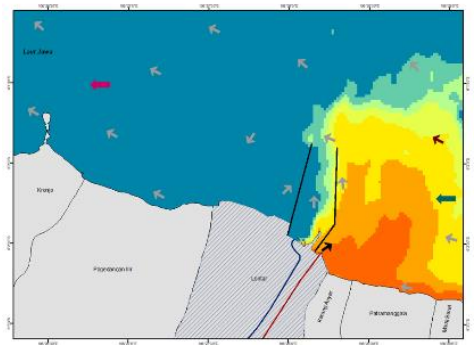

$\mathrm{n}$

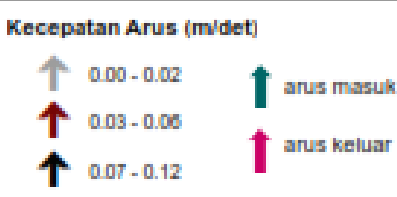

\section{Sumber Peta:}

1. Peta Rupa Bumi Indonesia 1:25.000 2. Peta Adendum Andal, Rencana Penaembanaan Unit 4 PLTU Banten 3
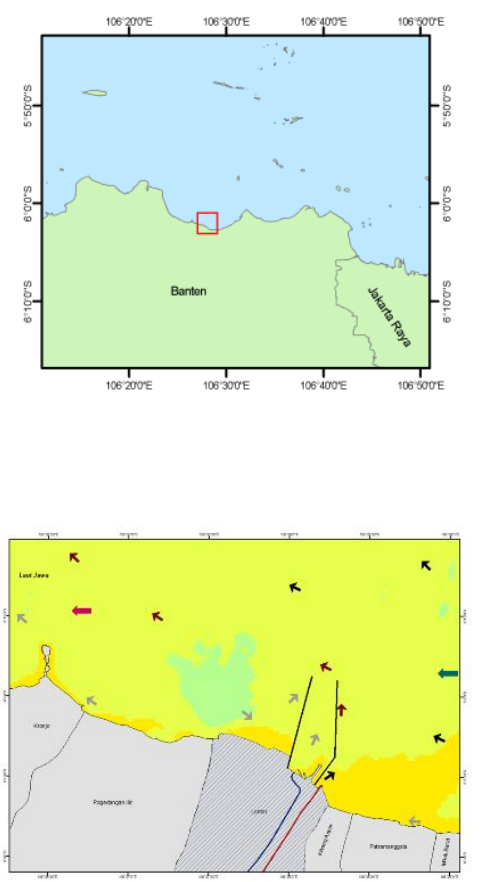

i

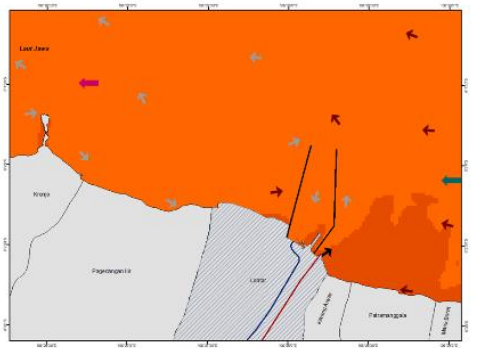

1

Gambar 4. Peta Arus Pasang Surut MIKE21 Pukul 03.00 WIB; a) 18 September 2019, b) 04 Oktober 2019, c) 22 April 2020, d) 13 September 2020, e) 15 Oktober 2020. 
Tabel 3. Perbandingan Pola Arus Pasang Surut Tahun 2019- 2020

\begin{tabular}{|c|c|c|c|c|}
\hline Gambar & Tanggal & $\begin{array}{c}\text { Kondisi Pasang } \\
\text { Surut }\end{array}$ & $\begin{array}{c}\text { Kec. Rata- } \\
\text { rata }(\mathrm{m} / \text { detik })\end{array}$ & Arah Dominan \\
\hline $4 a$ & 22 Mei 2019 & Pasang & 0.06 & Tenggara ke Barat Laut \\
\hline $4 \mathrm{~b}$ & 30 Juni 2019 & Pasang & 0.04 & Tenggara ke Barat Laut \\
\hline $4 c$ & 9 Juli 2019 & Pasang & 0.02 & Tenggara ke Barat Laut \\
\hline $4 d$ & 10 Agustus 2019 & Pasang & 0.05 & Tenggara ke Barat Laut \\
\hline $4 e$ & $\begin{array}{c}18 \text { September } \\
2019\end{array}$ & Pasang & 0.03 & Tenggara ke Barat Laut \\
\hline $4 \mathrm{f}$ & 04 Oktober 2019 & Pasang & 0.01 & Timur Laut ke Tenggara \\
\hline $4 \mathrm{~g}$ & 17 Januari 2020 & Pasang & 0.01 & Timur Laut ke Tenggara \\
\hline $4 \mathrm{~h}$ & 22 April 2020 & Pasang & 0.04 & Tenggara ke Barat Laut \\
\hline $4 \mathrm{i}$ & 24 Mei 2020 & Pasang & 0.06 & Timur ke Barat Laut \\
\hline $4 j$ & 16 Juni 2020 & Pasang & 0.03 & Timur ke Barat Laut \\
\hline $4 \mathrm{k}$ & 11 Juli 2020 & Pasang & 0.04 & Tenggara ke Barat Laut \\
\hline 41 & 28 Agustus 2020 & Pasang & 0.02 & Tenggara ke Barat Laut \\
\hline $4 \mathrm{~m}$ & $\begin{array}{c}13 \text { September } \\
2020\end{array}$ & Pasang & 0.02 & Tenggara ke Barat Laut \\
\hline $4 n$ & 15 Oktober 2020 & Pasang & 0.02 & Tenggara ke Barat Laut \\
\hline
\end{tabular}

Hasil pemodelan hidrodinamika menggunakan MIKE21 pada tahun 2014-2020 menggambarkan keadaan pola arus di perairan sekitar PLTU 3 Banten Lontar (Gambar 4). Pola pergerakan arus yang dibangkitkan oleh pasang surut dengan asumsi tidak ada pengaruh angin dan juga gesekan dasar. Waktu yang digunakan dalam pemodelan disesuaikan dengan waktu pengambilan data citra Landsat 8 yaitu pada 03.00 WIB. Kondisi perairan pada waktu tersebut menunjukkan dalam kondisi saat pasang. Arus pasan surut bergerak dengan rentang nilai kecepatan sebesar 0.01-0.51 m/det. Hasil pemodelan pada (Gambar 4a) memiliki kecepatan arus tercepat mencapai $0.51 \mathrm{~m} /$ det sedangkan kecepatan arus minimum ditunjukkan pada (Gambar 4f) mencapai $0.31 \mathrm{~m} /$ det. Berdasarkan Tabel 3 menunjukkan perbdaningan pola arus pasang surut tahun 2014-2020. Distribusi pergerakan arus pasang surut didominasi oleh arah arus yang bergerak dari Tenggara menuju Barat Laut dengan kecepatan arus rata- rata $0.03 \mathrm{~m} /$ det. Pergerakan arah arus akan mengalami pembelokkan yang disebabkan oleh adanya bangunan pantai atau jetty sehingga arus akan bergerak menuju ke dalam area pelabuhan.

\section{PEMBAHASAN}

\section{Sebaran Suhu Permukaan Laut di Perairan PLTU Banten 3 Lontar, Tangerang}

Pola persebaran suhu permukaan laut yang terdampak oleh limbah panas PLTU 3 Banten Lontar, Tangerang dapat diketahui melalui hasil pengolahan data Citra Landsat 8 TIRS hasil perekaman tahun 2019-2020 (Gambar 2). Hasil pengolahan data menunjukkan perbedaan warna pixel pada tiap data citra yang kemudian diklasifikasikan menjadi 10 kategori nilai suhu permukaan laut. Nilai tersebut ditampilkan dengan warna yang berbeda- beda dengan interval nilai suhu sebesar $1{ }^{\circ} \mathrm{C}$. Gambar 2 menunjukkan bahwa perairan memiliki suhu permukaan laut rata- rata berkisar antara $28.01{ }^{\circ} \mathrm{C}$ hingga $29.00{ }^{\circ} \mathrm{C}$. Nilai rentang tersebut sama dengan penelitian sebelumnya yang menyatakan bahwa Suhu Permukaan Laut di Perairan tersebut berkisar $29.00{ }^{\circ} \mathrm{C}$ (PLTU Lontar, 2015) .

Berdasarkan analisis secara spasial menunjukkan bahwa terdapat gradiasi nilai suhu permukaan laut dari PLTU 3 Banten Lontar. Wilayah yang terdampak limbah panas terkonsentrasi pada area outfall PLTU dengan intensitas kenaikan suhu permukaan laut cenderung melemah dari outfall pembangkit listrik secara bertahap. Variabilitas spasial intensitas kenaikan suhu permukaan laut sangat erat kaitannya dengan daerah di dekat outlet limbah panas PLTU. Gambar 2 menunjukkan bahwa limbah air panas memiliki variasi suhu permukaan laut berkisar 29.01 hingga 33.00 dimana $0.01-4{ }^{\circ} \mathrm{C}$ lebih tinggi dari suhu perairan sekitarnya, dengan intensitas kenaikan suhu melemah dari outfall pembangkit listrik didominasi ke arah Timur Laut. Dispersi penyebaran limbah yang berasal dari outlet pembuangan limbah panas PLTU menggambarkan pola penyebaran tidak memasuki area pelabuhan dikarenakan adanya bangunan pantai berupa Jetty PLTU sepanjang $160 \mathrm{~m}$. 
Hasil perhitungan luasan area terdampak limbah panas PLTU menunjukkan bahwa dispersi penyebaran limbah pada tahun 2019 memiliki total rata- rata luas mencapai 367.58 ha dan berada dalam jarak $1.76 \mathrm{~km}$ dari outfall sedangkan pada tahun 2020 memiliki total rata- rata penyebaran seluas 81.9 dan berada dalam jarak $1.38 \mathrm{~km}$ dari outfall PLTU Banten 3, Lontar. Daerah dengan kenaikan suhu sebesar $0.01{ }^{\circ} \mathrm{C}-1{ }^{\circ} \mathrm{C}$ memiliki cakupan area yang relatif terbesar dengan rata- rata luasan mencapai 328.877 ha dan sebagian besar berada dalam jarak $1.85 \mathrm{~km}$ dari outfall (Gambar 2.a, c, f, g, i, j, k, l, $\mathrm{m})$. Daerah dengan kenaikan suhu sebesar $1{ }^{\circ} \mathrm{C}$ dan $2{ }^{\circ} \mathrm{C}$ memiliki luasan rata- rata sebesar 62.54 ha dan berada dalam jarak $1.28 \mathrm{~km}$ dari outfall. Kenaikan suhu sebesar $3{ }^{\circ} \mathrm{C}$ dan $4{ }^{\circ} \mathrm{C}$ memiliki luas rata- rata mencapai 13.98 ha dan berada sejauh $0.94 \mathrm{~km}$ dari outfall (Gambar 2e).

Data lapangan yang diambil perekaman 31 Oktober 2020 pada saat perairan sedang pasang menunjukkan pola sebaran suhu permukaan laut membentuk gradasi warna merah yang memiliki nilai $34.01{ }^{\circ} \mathrm{C}-36.00{ }^{\circ} \mathrm{C}$ yang ditunjukkan dalam (Gambar 2f). Nilai suhu permukaan tersebut bisa terjadi di lingkungan PLTU sebagaimana yang dijelaskan oleh Nontji (2002), yang menyatakan bahwa suhu permukaan laut di perairan Indonesia pada beberapa wilayah di sekitar pembuangan limbah industri maupun pembangkit listrik dapat mencapai $32{ }^{\circ} \mathrm{C}$. Nilai yang tinggi pada hasil pengukuran lapangan dapat disebabkan oleh beberapa faktor. Faktor pertama yaitu pada saat pengambilan data sedang berlangsung pengeluaran limbah air panas ke perairan sehingga nilai yang terukur merupakan suhu permukaan laut yang belum tercampur dengan baik dengan air dari lingkungannya. Meskipun demikian, pola sebaran suhu permukaan laut pada pengukuran lapangan memiliki pola yang sama dengan pola sebaran hasil pengolahan citra Landsat 8 yaitu intensitas kenaikan suhu permukaan laut menurun dari outfall dan menjauhi garis pantai.

\section{Faktor Hidrooseanografi}

Berdasarkan hasil pemodelan hidrodinamika menggunakan Mike21 (Gambar 4) arus pasang surut penyebaran limbah air panas di perairan PLTU Banten 3 Lontar dipengaruhi oleh pergerakan arus pasang surut. Hal tersebut dapat ditunjukkan pada (Gambar 2.c, d, l, m) dan (Gambar 4.c, d, l, m) yang menggambarkan penyebaran limbah panas memiliki pola yang sama dengan distribusi pola arus pasang surut yang terjadi di perairan. Hal tersebut sama seperti pada penelitian sebelumnya yang menyatakan bahwa penyebaran panas di wilayah perairan dipengaruhi oleh faktor angin, arus musiman, dan arus pasang surut (Ahn et al., 2006; Wibowo dan Asvaliantina, 2018; Pintubatu et al., 2020). Arus pasang surut memiliki peran penting dalam terjadinya proses fisik yang paling mendasar yaitu transpor panas akibat masuknya limbah air panas ke dalam perairan (Cahyana, 2015).

\section{Verifikasi Data}

Verifikasi dilakukan dengan membandingkan nilai suhu permukaan laut Citra Landsat 8 TIRS pada 15 Oktober 2020 dengan suhu permukaan laut lapangan pada 31 Oktober 2020 dengan pertimbangan kedua waktu tersebut berada pada waktu dan periode musim yang sama. Hasil verifikasi data menunjukkan bahwa hasil pengukuran dan pengolahan data Citra Landsat 8 TIRS menghasilkan nilai RMSE 5.89 (Tabel 2) sehingga dapat dikatakan bahwa hasil verifikasi data suhu citra Landsat dengan data suhu hasil pengukuran kurang bagus.

Terdapat beberapa faktor penyebab hal tersebut. Penyebab pertama adalah adanya tutupan awan pada citra 31 Oktober 2020 yaitu sebesar $86.28 \%$ yang berdampak terhadap akurasi perekaman suhu permukan laut sehingga data tersebut tidak dapat dianalisa lebih lanjut. Hal tersebut seperti yang dijelaskan dalam (Fu et al., 2019) bahwa tutupan awan memiliki efek redaman yang jelas pada informasi inframerah termal, yang akan mengurangi akurasi inversi suhu permukaan laut. Dengan demikian, verifikasi data dilakukan dengan asumsi bahwa data pengukuran lapangan pada 31 Oktober 2020 memiliki waktu dan kondisi hidrooseanografi yang sama dengan data Citra Landsat 8 pada 15 Oktober 2020 .

Penyebab kedua adanya pengaruh perubahan lingkungan laut, seperti batimetri, massa daratan, dataran pasang surut, arus pasang surut, debit sungai, dan sebagainya, sebagaimana yang dijelaskan oleh Jang dan Park (2019). Penyebab ketiga adalah ketidaksesuaian waktu antara akuisisi data suhu permukaan laut Citra Landsat 8 TIRS dengan waktu pengukuran data suhu permukaan laut lapangan. Pengambilan data lapangan dilakukan pada 16 hari setelah hasil dari interpretasi data Citra Landsat 8 TIRS. Hal tersebut dikarenakan data Citra Landsat 8 TIRS pada saat data lapangan diambil memiliki tutupan awan yang cukup tinggi. Perbedaan waktu pengukuran suhu permukaan laut lapangan dengan 
perekaman Citra Landsat 8 TIRS yang masing- masing diambil pada waktu 10.00-11.00 WIB dan 03.00 WIB mengakibatkan terjadinya perbedaan penyinaran sinar matahari ke badan perairan sehingga terjadi perbedaan penyinaran sinar matahari ke badan perairan sehingga terjadi perbedaan antara suhu permukaan laut yang diukur dengan suhu hasil perekaman citra.

\section{KESIMPULAN}

Sebaran suhu permukaan laut berdasarkan hasil pengolahan Citra Landsat 8 TIRS dan pengolahan data lapangan menggambarkan dominasi penyebaran ke arah Timur Laut dan mengalami penurunan nilai suhu dari daerah pantai menuju laut lepas. Wilayah yang diperkirakan terdampak dari limbah air panas memiliki rentang nilai suhu permukaan laut yaitu $29.01{ }^{\circ} \mathrm{C}-33.00{ }^{\circ} \mathrm{C}$. Pola sebaran spasial suhu permukaan laut secara horizontal dipengaruhi oleh arus pasang surut yang bergerak dengan kecepatan $0.014-0.519 \mathrm{~m} / \mathrm{det}$.

Hasil perhitungan luasan area terdampak limbah panas PLTU menunjukkan bahwa dispersi penyebaran limbah pada tahun 2019 memiliki total rata- rata luas mencapai 362.58 ha dan berada dalam jarak $1.26 \mathrm{~km}$ dari outfall sedangkan pada tahun 2020 memiliki total rata- rata penyebaran seluas 81.9 dan berada dalam jarak $1.38 \mathrm{~km}$ dari outfall PLTU Banten 3, Lontar.

\section{DAFTAR PUSTAKA}

Ahn, Y. H., P. Shanmugam, J. H. Lee, dan Y. Q. Kang. 2006. Application of Satellite Infrared Data for Mapping of Thermal Plume Contamination in Coastal Ecosystem of Korea. Mar. Environ. Res., 61(2):186-201

Akhbar, A. I., Y. V. Jaya, dan T. Febrianto. 2018. Kajian Suhu Permukaan Laut Berdasarkan Data Citra Satelit NOAA-AVHRR dan Data Argo Float Di Perairan Selatan Jawa, Dinamika Maritim. 2(1):22-32.

Cahyana, C. 2011. Model Sebaran Panas Air Kanal Pendingin Instalasi Pembangkit Listrik ke Badan Air Laut. In Prosiding Seminar Nasional Teknologi Pengelolaan Limbah IX, Pusat Teknologi Limbah Radioaktif-BATAN dan FT-Universitas Sultan Ageng Tirtayasa. 5: 293-302.

Cherif, E. K., F. Salmoun, and F. J. Mesas-Carrascosa. 2019. Determination of Bathing Water Quality Using Thermal Images Landsat 8 on the West Coast of Tangier: Preliminary Results. Remote Sens., 11(8).

Fu, J., C. Chen, H. Ren, Y. Zhang, dan Y. Chu. 2019. Sea Surface Temperature Retrieval from Landsat8 Thermal Infrared Remote Sensing Data in Coastal Waters. IOP Conf. Ser. Earth Environ. Sci., 310(3).

Fudlailah, P. dan M. Zikra. 2013. Pemodelan Penyebaran Limbah Panas Di Wilayah Pesisir (Studi Kasus Outfall PLTU Paiton). J. Tek. Kelaut.:1-8.

Ismayati, Q., M. Helmi, B. Rochaddi. 2013. Kajian Spasial Suhu Permukaan Laut Akibat Air Bahang Pltu Paiton Menggunakan Saluran Termal Satelit Landsat 2/Etm+ Di Pantai Bhinor Kabupaten Probolinggo Jawa Timur. J. Oceanogr., 2(1):49-56.

Jang, J. C. dan K. A. Park. 2019. High-Resolution Sea Surface Temperature Retrieval from Landsat 8 OLI/TIRS Data at Coastal Regions. Remote Sens., 11(22).

Kusuma, D. W., A. Murdimanto, L. Y. Aden, B. Sukresno, D. Jatisworo, dan R. Hanintyo. 2012. Sea Surface Temperature Dynamics in Indonesia. IOP Conf. Ser. Earth Environ. Sci., 98(1).

McPhaden, M. J. dan S. P. Hayes. 1991. On the Variability of Winds, Sea Surface Temperature, dan Surface Layer Heat Content in the Western Equatorial Pacific. J. Geophys. Res., 96(S01):3331.

Mukhlisin, A. and S. Soemarno. 2020. Estimasi Kandungan Klorofil Tanaman Kopi Robusta (Coffea Canephora Var. Robusta) Menggunakan Normalized Difference Vegetation Index (Ndvi) Di Bangelan, Wonosari, Malang. J. Tanah dan Sumberd. Lahan, 2(2):329-339.

Mutaqin, B. dan B. Angga. 2013. Analisa Spasial Sebaran Suhu Permukaan Laut Di Perairan Jepara Menggunakan Citra Landsat 8. In: Pros. Simp. Nas. Sains Geoinformasi.

Neill, S. P. dan M. R. Hashemi. 2018. Ocean Modelling for Resource Characterization, 193- 235 p.

Nontji, A. 2002. Laut Nusantara. Cetakan kelima. Penerbit Djambatan: 322 pp.

Pintubatu, K. L., S. Widada, J. Marwoto, dan A. Satriadi. 2020. Studi Pola Sebaran Suhu Permukaan Laut Akibat Air Bahang Pembangkit Listrik Tenaga Uap ( PLTU ) Paiton Probolinggo Jawa Timur. Indones. J. Oceanogr., 02:0-8. 
PLTU Lontar. 2015. Adendum Analisis Dampak Lingkungan Hidup (ADENDUM ANDAL).

Rosen, M. A., C. A. Bulucea, N. E. Mastorakis, C. A. Bulucea, A. C. Jeles, dan C. C. Brindusa. 2015. Evaluating the Thermal Pollution Caused by Wastewaters Discharged from a Chain of CoalFired Power Plants along a River. Sustain., 2(5):5920-5943.

Sari, Y. N., A. Wirasatriya, B. Rochaddi, dan G. Hdanoyo. 2020. Variabilitas Arus Permukaan Di Perairan Samudra Hindia Selatan Jawa. Indones. J. Oceanogr., 02(01).

Setiawan, A. N., Y. Dhahiyat, dan N. P. Purba. 2013. Variasi Sebaran Suhu Dan Klorofil-a Akibat Pengaruh Arlindo Terhadap Distribusi Ikan Cakalang Di Selat Lombok. Depik J., 2(2):58-69.

Surinati, D. dan M. R. Marfatah. 2019. Pengaruh Faktor Hidrodinamika Terhadap Sebaran Limbah Air Panas Di Laut. Oseana, 44(1):26-32.

Tampubolon, A. B., O. Gustin, dan S. N. Chayati. 2012. Pemetaan Suhu Permukaan Laut Menggunakan Menggunakan Citra Satelit Aqua Modis Di Perairan Provinsi Kepulauan Riau. Tek. Inf.(May).

Trisakti, B., S. Sulma, dan S. Budhiman. 2004. Study of Sea Surface Temperature (SST) Using Landsat2 ETM (In Comparison with Sea Surface Temperature of NOAA-12 AVHRR). Thirteen. Work. Omi.(May 2016):18-1 to 18-5.

Wibowo, M. dan V. Asvaliantina. 2018. Kajian Dispersi Panas Akibat Air Limbah Rencana Pembangunan PLTU Kuala Tungkal - Provinsi Jambi. J. Teknol. Lingkung., 19(1):1.

Yani, A dan Ruhimat, M. 2002. Geologi. Bandung : Gralindo Media Pratama. 